\title{
Pencegahan dan Pengendalian Infeksi Silang pada Tindakan Ekstraksi Gigi di Poli Gigi Rumah Sakit Siloam Manado
}

\author{
Rachel Gabriele \\ Vonny N. S. Wowor \\ Aurelia Supit \\ Program Studi Pendidikan Dokter Gigi Fakultas Kedokteran \\ Universitas Sam Ratulangi Manado \\ Email: rachelpangab@gmail.com
}

\begin{abstract}
Prevention and control of cross infection is very important for dental health workers, especially in dental extraction because this action is directly related to blood and saliva. The risk of infection requires thorough attention of dental health workers. This study was aimed to determine the level of prevention and control of cross infection in dental extraction at Dental Clinic of Siloam Hospital Manado. This wass an observational descriptive study, with a total samples of 30 operators. The results showed that the prevention and control of cross infection before dental extraction performed was $61.71 \%$; during dental extraction was $73.34 \%$; and after dental extraction was $92.08 \%$. Generally, the prevention and control of cross infection in dental extraction only achieved $75.71 \%$. In conclusion, the prevention and control of cross infection in dental extraction at Siloam Hospital, Manado was still below maximum level.
\end{abstract}

Keywords: prevention control of cross infection, dental extraction

\begin{abstract}
Abstrak: Pencegahan dan pengendalian infeksi silang merupakan hal yang sangat penting bagi tenaga kesehatan gigi, terlebih lagi pada ekstraksi gigi, karena tindakan ini berhubungan langsung dengan darah dan saliva. Risiko infeksi mengharuskan tenaga kesehatan gigi memerhatikan tindakan pencegahan dan pengendalian infeksi. Penelitian ini bertujuan untuk mengetahui tingkat pencegahan dan pengendalian infeksi silang pada tindakan ekstraksi gigi di poliklinik gigi Rumah Sakit Siloam Manado. Jenis penelitian ialah deskriptif observasional, dengan jumlah subyek sebanyak 30 operator. Hasil penelitian mendapatkan pencegahan dan pengendalian infeksi silang sebelum tindakan ekstraksi gigi dilakukan sebesar $61,71 \%$; selama tindakan ekstraksi gigi sebesar 73,34\%; dan setelah tindakan ekstraksi gigi sebesar 92,08\%. Secara umum, pencegahan dan pengendalian infeksi silang pada tindakan ekstraksi gigi hanya dilakukan sebesar $75,71 \%$. Simpulan penelitian ini ialah pencegahan dan pengendalian infeksi silang pada tindakan ekstraksi gigi di poliklinik gigi Rumah Sakit Siloam Manado belum maksimal.
\end{abstract}

Kata kunci: pencegahan dan pengendalian infeksi silang, ekstraksi gigi

Pencapaian derajat kesehatan yang optimal merupakan tujuan dari pembangunan kesehatan. ${ }^{1}$ Tercapainya derajat hidup sehat yang optimal dipengaruhi oleh beberapa faktor. Teori Blum menyatakan bahwa terdapat empat faktor yang memengaruhi derajat kesehatan, yakni faktor lingkungan, perilaku, pelayanan kesehatan, dan faktor keturunan (herediter). ${ }^{1,2}$ Walaupun faktor pelayanan kesehatan yang mencakup sarana prasarana pelayanan kesehatan serta tenaga kesehatan bukan merupakan faktor yang terbesar pengaruhnya, namun merupakan faktor penting yang tidak dapat diabaikan. Tenaga kesehatan bukan saja dituntut kemampuan dalam hal pengetahuan dan 
keterampilan sesuai bidang ilmunya, namun juga sisi profesionalismenya berkaitan dengan kepatuhannya untuk melakukan perawatan berdasarkan standar prosedur operasional yang sudah ada, karena ketidakpatuhan terhadap standar opersional prosedur bisa berdampak kurang baik antara lain terhadap kesehatan pasien yang dirawat, operatornya sendiri, tenaga kesehatan lain serta masyarakat. ${ }^{3}$

Pembangunan kesehatan hingga saat ini terus giat dilaksanakan oleh pemerintah mengingat kesehatan termasuk kesehatan gigi mulut masih menjadi masalah hingga saat ini. Salah satunya yaitu pemberadaan fasilitas kesehatan serta tenaga dokter termasuk dokter gigi. ${ }^{1}$

Ketersediaan fasilitas saja belum cukup, tetapi harus dibarengi dengan pelayanan kesehatan yang terjamin keamanannya bagi tenaga kesehatan serta masyarakat yang dilayani atau yang terkait di dalamnya. Pemberian jaminan keamanan kesehatan ialah wajib baik bagi tenaga kesehatan maupun masyarakat yang harus dilayani. $^{3}$ Lingkungan kerja kedokteran gigi merupakan salah satu aspek tercapainya keamanan kesehatan karena lingkungan kerja dapat menjadi sumber penularan infeksi. Untuk itu sarana pelayanan kesehatan perlu memberi perlindungan bagi pasien, tenaga kesehatan, tenaga pendukung dan komunitas masyarakat dalam setiap tindakan perawatan gigi dan mulut. ${ }^{1,3}$

Hasil Riset Kesehatan Dasar (Riskesdas) tahun 2018 menunjukkan prevalensi nasional masalah gigi dan mulut di Indonesia sebesar 57,6\%. Penyakit gigi dan mulut seperti karies gigi dan penyakit periodontal dapat ditangani oleh beberapa tindakan, salah satunya melalui tindakan ekstraksi. ${ }^{4}$ Tindakan ekstraksi gigi merupakan cara termudah dan terbaik untuk menghilangkan sakit gigi, apabila gigi tersebut tidak dapat dipertahankan lagi. ${ }^{5}$ Profil Kesehatan Provinsi Sulawesi Utara tahun 2016 menunjukkan bahwa masyarakat di Kota Manado yang mendapat pelayanan ekstraksi gigi yaitu sebanyak 1.261 dan ini merupakan angka kedua terbanyak di Provinsi Sulawesi Utara.
Angka ini menunjukkan bahwa tindakan ekstraksi gigi merupakan tindakan yang banyak dilakukan di Kota Manado. ${ }^{6}$

Tindakan ekstraksi merupakan salah satu tindakan yang memiliki risiko tinggi dalam penularan infeksi. ${ }^{5}$ Penatalaksanaan ekstraksi gigi yang tidak sesuai standar prosedur operasional atau mengabaikan prinsip-prinsip pencegahan dan pengendalian infeksi, dapat mengakibatkan terjadinya infeksi silang. Virus seperti HIV (Human Immunodeficiency Virus) dan hepatitis B yang dapat terbawa melalui darah dan saliva berpotensi menyebabkan infeksi silang lewat kontaminasi yang terjadi. $^{7}$ Lewat tindakan ekstraksi gigi, penyebaran agen infeksi di praktik dokter gigi dapat terjadi melalui pasien ke tenaga kesehatan gigi, tenaga kesehatan gigi ke pasien, pasien ke pasien, tenaga kesehatan ke komunitas termasuk keluarga tenaga kesehatan. ${ }^{8}$ Hasil penelitian Center of Disease Control and Prevention (CDC) terhadap 360 orang tenaga kesehatan yang mengalami kejadian luka karena jarum suntik di tempat praktek, $36 \%$ di antaranya dialami oleh dokter gigi, 34\% dialami oleh ahli bedah mulut, $22 \%$ dialami oleh perawat gigi, dan $4 \%$ dialami oleh mahasiswa kedokteran gigi sehingga penularan infeksi dari tindakan ekstraksi menjadi bahaya yang sangat nyata pada praktik pelayanan kedokteran gigi.,

Adanya berbagai latar belakang masalah yang dikemukan di atas menjadi alasan bagi penulis untuk meneliti tentang pencegahan dan pengendalian infeksi pada tindakan ekstraksi gigi. Penulis memilih Rumah sakit Siloam Manado sebagai lokasi penelitian oleh karena rumah sakit ini merupakan salah satu rumah sakit yang terkenal di Kota Manado dan memiliki poliklinik gigi untuk pelayanan kesehatan gigi bagi masyarakat kota Manado dan sekitarnya. Di samping itu penulis ingin mendapatkan informasi lebih dalam mengenai pelaksanaan pencegahan pengendalian infeksi di Rumah Sakit Siloam yang merupakan salah satu rumah sakit tipe B, setelah sebelumnya pernah melakukan praktik lapangan untuk melakukan penga- 
matan secara umum tentang pelaksanaan manajemen praktik pelayanan kedokteran gigi di rumah sakit tersebut.

\section{METODE PENELITIAN}

Penelitian ini dilakukan dengan menggunakan metode deskriptif observasional. Penelitian dilaksanakan selama bulan April-Mei 2019 dengan jumlah responden yang diteliti sebanyak 30 operator yang diambil dengan teknik total sampling. Data diambil langsung oleh peneliti dengan cara mengisi lembar penelitian berupa check list, diisi berdasarkan tindakan pencegahan dan pengendalian yang dilakukan oleh operator. Data kemudian diolah secara manual dan disajikan berdasarkan distribusi frekuensi dalam bentuk tabel.

\section{HASIL PENELITIAN}

Pencegahan dan pengendalian infeksi silang pada tindakan ekstraksi gigi terbagi atas pencegahan dan pengendalian infeksi silang sebelum tindakan ekstraksi gigi, selama tindakan ekstraksi gigi, setelah tindakan ekstraksi gigi, dan penatalaksanaan kecelakaan kerja.

Tabel 1 menunjukkan bahwa $80 \%$ ope- rator melakukan tindakan desinfeksi pada pegangan lampu, semua operator $(100 \%)$ melakukan tindakan desinfeksi pada sandaran kepala, 53,33\% operator melakukan tindakan desinfeksi pada unit kontrol, $23,33 \%$ operator melakukan tindakan desinfeksi pada tombol semprit air-udara, dan 33,33\% operator melakukan tindakan desinfeksi pada meja instrumen.

Tabel 2 menunjukkan bahwa semua (100\%) operator telah divaksinasi hepatitis $\mathrm{B}$, memakai sarung tangan, masker, dan sepatu tertutup; operator yang mencuci tangan dengan teknik enam langkah sebelum memakai sarung tangan, yaitu $56,67 \%$; operator yang memakai pakaian pelindung kerja/ baju kerja, yaitu $66,67 \%$; sedangkan peggunaan sarung tangan bedah steril dan kacamata pelindung sama sekali tidak diterapkan.

Tabel 3 menunjukkan bahwa semua (100\%) asisten operator telah divaksinasi hepatitis B, memakai sarung tangan, masker, sepatu tertutup, dan pakaian pelindung/baju kerja; sedangkan cuci tangan sebelum memakai sarung tangan, peggunaan sarung tangan bedah steril dan kacamata pelindung tidak diterapkan.

Tabel 1. Distribusi frekuensi tindakan desinfeksi permukaan kerja

\begin{tabular}{lcccc}
\hline Tindakan desinfeksi & \multicolumn{2}{c}{ Ya } & \multicolumn{2}{c}{ Tidak } \\
& $\mathrm{n}$ & $\%$ & $\mathrm{n}$ & $\%$ \\
\hline Pegangan lampu & 24 & 80,0 & 6 & 20,0 \\
Sandaran kepala & 30 & 100,0 & 0 & 0 \\
Unit control & 16 & 53,33 & 14 & 46,67 \\
Tombol semprit air-udara & 7 & 23,33 & 23 & 76,67 \\
Meja instrumen & 10 & 33,33 & 20 & 66,67 \\
Rerata & & 58,00 & & 42,00 \\
\hline
\end{tabular}

Tabel 2. Distribusi frekuensi perlindungan pribadi operator

\begin{tabular}{lcccc}
\hline \multicolumn{1}{c}{ Bentuk perlindungan pribadi } & \multicolumn{2}{c}{ Ya } & \multicolumn{2}{c}{ Tidak } \\
& $\mathrm{n}$ & $\%$ & $\mathrm{n}$ & $\%$ \\
\hline Vaksinasi hepatitis B & 30 & 100,0 & 0 & 0 \\
Mencuci tangan sebelum memakai sarung tangan & 17 & 56,67 & 13 & 43,33 \\
Memakai sarung tangan & 30 & 100,0 & 0 & 0 \\
Memakai sarung tangan bedah steril & 0 & 0 & 30 & 100,0 \\
Memakai masker & 30 & 100,0 & 0 & 0 \\
Memakai kacamata pelindung & 0 & 0 & 30 & 100 \\
Memakai pakaian pelindung/baju kerja & 20 & 66,67 & 10 & 33,33 \\
Memakai sepatu tertutup & 30 & 100,0 & 0 & 0 \\
Rerata & & 65,42 & & 34,58 \\
\hline
\end{tabular}


Tabel 3. Distribusi frekuensi perlindungan pribadi asisten operator

\begin{tabular}{lccccc}
\hline \multicolumn{2}{c}{ Bentuk perlindungan pribadi } & \multicolumn{2}{c}{ Ya } & \multicolumn{2}{c}{ Tidak } \\
\cline { 2 - 5 } & $\mathrm{n}$ & $\%$ & $\mathrm{n}$ & $\%$ \\
\hline Vaksinasi hepatitis B & 30 & 100,0 & 0 & 0 \\
Mencuci tangan sebelum memakai sarung & 0 & 0 & 30 & 100,0 \\
tangan & & & & \\
Memakai sarung tangan & 30 & 100,0 & 0 & 0 \\
Memakai sarung tangan bedah steril & 0 & 0 & 30 & 100,0 \\
Memakai masker & 30 & 100,0 & 0 & 0 \\
Memakai kacamata pelindung & 0 & 0 & 30 & 100,0 \\
Memakai pakaian pelindung/baju kerja & 30 & 100,0 & 0 & 0 \\
Memakai sepatu tertutup & 30 & 100,0 & 0 & 0 \\
Rerata & & 62,5 & & 37,5 \\
\hline
\end{tabular}

Tabel 4 memperlihatkan bahwa $42 \%$ operator tidak melakukan tindakan desinfeksi permukaan kerja, $65,42 \%$ operator memakai alat pelindungan pribadi, dan asisten operator yang memakai alat pelindung pribadi yaitu $62,5 \%$. Pencegahan dan pengendalian infeksi silang sebelum tindakan ekstraksi gigi hanya dilakukan sebesar $61,97 \%$.

Tabel 5 menunjukkan bahwa semua $(100 \%)$ operator melakukan pemberian desinfektan sebelum insersi jarum suntik, jarum suntik ditutup setelah tindakan anestesi dan menghindari tertusuk instrumen dan jarum yang tajam; tangan operator tidak menyentuh lingkungan kerja/ peralatan yang tidak steril, yaitu sebesar $66,67 \%$ dan jumlah terendah yaitu berkumur dengan larutan antiseptik dimana tidak ada operator yang melakukan tindakan tersebut.

Tabel 4. Distribusi frekuensi pencegahan dan pengendalian infeksi silang sebelum tindakan ekstraksi gigi

\begin{tabular}{lcc}
\hline Tindakan pencegahan dan pengendalian infeksi & Ya & Tidak \\
\cline { 2 - 3 } silang sebelum tindakan ekstraksi gigi & $\%$ & $\%$ \\
\hline Desinfeksi permukaan kerja & 58,0 & 42,0 \\
Perlindungan pribadi operator & 65,42 & 34,58 \\
Perlindungan pribadi asisten operator & 62,5 & 37,5 \\
Rerata & 61,97 & 38,03 \\
\hline
\end{tabular}

Tabel 5. Distribusi frekuensi pencegahan dan pengendalian infeksi silang selama tindakan ekstraksi gigi

\begin{tabular}{|c|c|c|c|c|}
\hline \multirow{2}{*}{$\begin{array}{l}\text { Tindakan pencegahan dan pengendalian infeksi } \\
\text { silang selama tindakan ekstraksi gigi }\end{array}$} & \multicolumn{2}{|c|}{ Ya } & \multicolumn{2}{|c|}{ Tidak } \\
\hline & $\mathrm{n}$ & $\%$ & $\mathrm{~N}$ & $\%$ \\
\hline Pasien berkumur dengan larutan antiseptik & 0 & 0 & 30 & 100,0 \\
\hline $\begin{array}{l}\text { Pemberian desinfektan sebelum insersi jarum } \\
\text { suntik }\end{array}$ & 30 & 100,0 & 0 & 0 \\
\hline Jarum suntik ditutup setelah tindakan anestesi & 30 & 100,0 & 0 & 0 \\
\hline $\begin{array}{l}\text { Menghindari tertusuk instrumen tajam yang sudah } \\
\text { terkontaminasi }\end{array}$ & 30 & 100,0 & 0 & 0 \\
\hline $\begin{array}{l}\text { Tangan operator tidak menyentuh } \\
\text { lingkungan/permukaan kerja yang tidak steril }\end{array}$ & 20 & 66,67 & 10 & 33,33 \\
\hline Rerata & & 73,34 & & 26,66 \\
\hline
\end{tabular}


Tabel 6 menunjukkan semua $(100 \%)$ operator melakukan tindakan pencegahan dan pengendalian setelah tindakan ekstraksi, kecuali tindakan mencuci tangan asepsis setelah sarung tangan dibuka oleh operator, yaitu sebanyak $36,67 \%$.

Hasil penelitian menunjukkan bahwa tidak adanya kecelakaan kerja yang terjadi selama penelitian berlangsung.

Tabel 7 menunjukkan bahwa pence- gahan dan pengendalian infeksi silang sebelum tindakan, yaitu $61,97 \%$. Pencegahan dan pengendalian infeksi silang selama tindakan, yaitu 73,34\%. Pencegahan dan pengendalian infeksi silang setelah tindakan, yaitu 92,96\%. Secara keseluruhan pencegahan dan pengendalian infeksi silang sebelum tindakan, selama tindakan dan setelah tindakan, yaitu sebesar 76,09\%.

Tabel 6. Distribusi frekuensi pencegahan dan pengendalian infeksi silang setelah tindakan ekstraksi gigi

\begin{tabular}{|c|c|c|c|c|}
\hline \multirow{2}{*}{$\begin{array}{l}\text { Pencegahan dan pengendalian setelah tindakan } \\
\text { ekstraksi gigi }\end{array}$} & \multicolumn{2}{|c|}{$\mathbf{Y a}$} & \multicolumn{2}{|c|}{ Tidak } \\
\hline & $\mathrm{n}$ & $\%$ & $\mathrm{n}$ & $\%$ \\
\hline \multicolumn{5}{|l|}{ Cuci tangan setelah sarung tangan dibuka: } \\
\hline Operator & 11 & 36,67 & 19 & 63,33 \\
\hline Asisten operator & 30 & 100,0 & 0 & 0 \\
\hline $\begin{array}{l}\text { Menggunakan sarung tangan karet tebal sebelum } \\
\text { mencuci instrumen bekas pakai. }\end{array}$ & 30 & 100,0 & 0 & 0 \\
\hline $\begin{array}{l}\text { Pemindahan baki instrumen dari daerah kerja ke } \\
\text { daerah dekontaminasi dalam keadaan tertutup. }\end{array}$ & 30 & 100,0 & 0 & 0 \\
\hline $\begin{array}{l}\text { Pemindahan instrumen yang terkontaminasi tidak } \\
\text { melewati daerah yang steril. }\end{array}$ & 30 & 100,0 & 0 & 0 \\
\hline $\begin{array}{l}\text { Pembersihan instrumen bekas pakai dengan air, sikat } \\
\text { dan deterjen }\end{array}$ & 30 & 100,0 & 0 & 0 \\
\hline Sterilisasi instrumen & 30 & 100,0 & 0 & 0 \\
\hline $\begin{array}{l}\text { Menempatkan sampah infeksius pada kontainer } \\
\text { warna kuning }\end{array}$ & 30 & 100,0 & 0 & 0 \\
\hline $\begin{array}{l}\text { Menempatkan sampah non infeksius pada kontainer } \\
\text { warna hitam }\end{array}$ & 30 & 100,0 & 0 & 0 \\
\hline Rerata & & 92,96 & & 7,04 \\
\hline
\end{tabular}

Tabel 7. Distribusi frekuensi pencegahan dan pengendalian infeksi silang sebelum tindakan, selama tindakan, dan setelah tindakan ekstraksi gigi

\begin{tabular}{lcc}
\hline Pencegahan dan pengendalian infeksi silang & Ya & Tidak \\
\hline Sebelum tindakan ekstraksi gigi & $61,97 \%$ & $38,03 \%$ \\
Selama tindakan ekstraksi gigi & $73,34 \%$ & $26,66 \%$ \\
Setelah tindakan ekstraksi gigi & $92,96 \%$ & $7,04 \%$ \\
Penatalaksanaan kecelakaan kerja & - & - \\
Rerata & $76,09 \%$ & $23,91 \%$ \\
\hline
\end{tabular}

\section{BAHASAN}

Pencegahan dan pengendalian infeksi silang sebelum tindakan ekstraksi gigi meliputi tindakan desinfeksi permukaan kerja, perlindungan pribadi operator, dan perlindungan pribadi asisten oprator.

Hasil penelitian tindakan desinfeksi pada permukaan kerja, menunjukkan hasil bahwa hanya $58 \%$ responden yang melakukan tindakan desinfeksi pada permukaan kerja dengan larutan desinfektan. Permukaan kerja biasanya dibersihkan oleh asisten operator setelah pemakaian dental unit dan pembersihan yang dilakukan 
menggunakan kertas tisu kering yang diberi larutan desinfektan. Pada tombol kontrol semprit air-udara dan permukaan meja instrumen diperoleh hasil terendah yaitu $23,33 \%$ dan 33,33\%. Meja instrumen hanya dilapisi dengan polybibs towel yang tidak bisa menutupi semua bagian meja instrumen karena ukurannya tidak sesuai dimana seharusnya meja instrumen dilapisi menggunakan plastik wrap yang dapat dibentuk sesuai dengan permukaan dan dapat melekat dengan baik agar percikan saliva dan darah yang terpancar saat bekerja tidak langsung mengenai permukaan kerja.

Hasil penelitian perlindungan pribadi operator menunjukkan $65,42 \%$ responden yang melakukan perlindungan pribadi. Semua (100\%) operator sudah divaksinasi Hepatitis B. Hal ini menunjukkan bahwa seluruh responden sadar akan pentingnya proteksi diri bagi petugas kesehatan gigi.

Sebanyak $56,67 \%$ responden mencuci tangan sebelum memakai sarung tangan. Mencuci tangan sebelum memakai sarung tangan merupakan tindakan yang penting dilakukan guna menghilangkan kotoran dan debu secara mekanis dari permukaan kulit serta mengurangi jumlah mikroorganisme sementara, tetapi dalam keadaan terdesak responden mengabaikan tindakan ini. $^{5}$

Semua $(100 \%)$ responden memakai alat pelindung pribadi yaitu sarung tangan dan masker. Hal ini sejalan dengan penelitian yang dilakukan oleh Suleh ${ }^{10}$ yakni semua operator $(100 \%)$ memakai sarung tangan dan masker. Sarung tangan yang dipakai pada tindakan ekstrasi gigi ialah sarung tangan periksa yang terbuat dari bahan vinil yang tipis dan mudah sobek. Seharusnya operator menggunakan sarung tangan bedah steril. Masker yang dipakai merupakan masker dari bahan katun dan kertas sedangkan sebaiknya operator memakai masker respirator untuk menyaring udara yang masuk saat menarik nafas.

Semua (100\%) responden tidak memakai kacamata pelindung. Responden menganggap memakai kacamata pelindung saat bekerja sangat mengganggu kenyamanan saat bekerja padahal kacamata pelindung telah disediakan oleh pihak rumah sakit dan ha ini penting untuk menghindari permukaan selaput lendir di mata terhadap percikan darah dan saliva dari pasien saat bekerja.

Semua $(100 \%)$ responden memakai sepatu tertutup. Pemakaian sepatu tertutup bertujuan untuk melindungi tertusuknya kaki dari instrumen ketika ada instrumen yang terjatuh. Hasil yang ada memperlihatkan bahwa operator sadar akan pentingnya memakai sepatu tertutup.

Hasil penelitian perlindungan pribadi asisten operator menunjukkan $62,5 \%$ responden menggunakan perlindungan pribadi. Semua $(100 \%)$ operator telah divaksinasi hepatitis B.

Hasil penelitian perlindungan pribadi dengan teknik barrier praktis memperlihatkan bahwa semua (100\%) responden tidak mencuci tangan sebelum memakai sarung tangan. Kondisi yang ada di poliklinik gigi rumah sakit ketika asisten operator menuliskan lembar rekam medis, terkadang operator meminta asisten operator untuk segera membantu melakukan tindakan terhadap pasien sehingga asisten operator terburu-buru untuk memakai sarung tangan dan tidak melakukan cuci tangan asepsis padahal hal ini sangat diperlukan.

Semua (100\%) responden memakai alat pelindung pribadi yaitu sarung tangan, masker, pakaian pelindung, dan sepatu tertutup. Hal ini menunjukkan kesadaran responden akan pentingnya alat pelindung pribadi guna mencegah terjadinya infeksi silang. semua (100\%) asisten operator tidak memakai kacamata pelindung.

Pencegahan dan pengendalian infeksi silang selama tindakan ekstraksi gigi memperoleh hasil 73,34\%. Tindakan asepsis pada pasien yaitu berkumur dengan larutan antiseptik tidak sama sekali dilakukan oleh responden Hasil ini sejalan dengan penelitian yang dilakukan oleh Ramdhani $^{11}$ padahal tindakan berkumur dengan larutan antiseptik terbukti dapat mengurangi jumlah mikroba rongga mulut sampai $90 \%$.,11

Pemberian desinfeksi sebelum insersi jarum suntik sudah dilakukan oleh semua $(100 \%)$ responden dengan menggunakan 
larutan betadine yang dioles menggunakan cotton pellet pada daerah kerja di rongga mulut yang akan menjadi tempat insersi jarum suntik.

Tindakan pencegahan kecelakaan kerja, yaitu penutupan jarum suntik setelah tindakan anestesi, dilakukan oleh semua $(100 \%)$ responden tetapi penutupan jarum suntik tersebut hampir tidak dilakukan dengan teknik satu tangan. Jika hal ini terus dilakukan maka risiko terjadinya penularan infeksi silang akan meningkat apabila kebetulan pasien sedang terinfeksi.

Tindakan pencegahan penularan infeksi melalui operator dimana tangan responden yang adalah operator tidak menyentuh lingkungan/permukaan kerja yang tidak steril, diperoleh hasil yaitu sebanyak 66,67\% yang melakukannya. Kondisi yang ada di rumah sakit terkadang saat operator sedang bekerja, tenaga asisten yang ada mempersiapkan hal yang lain seperti mengambil instrumen sehingga operator terpaksa menyentuh permukaan kerja yang tidak steril.

Hasil penelitian pencegahan dan pengendalian infeksi silang setelah tindakan ekstraksi gigi menunjukkan rerata tertinggi yaitu $92,08 \%$. Tindakan mencuci tangan asepsis setelah sarung tangan dibuka hanya dilakukan oleh $36,67 \%$ operator. Saat selesainya tindakan ekstraksi gigi, operator hanya memiliki waktu yang terbatas dikarenakan banyaknya pasien yang harus dilayani sehingga dalam keadaan terdesak operator tidak melakukan prosedur mencuci tangan. Di sisi lain, semua $(100 \%)$ asisten operator melakukan tindakan mencuci tangan setelah sarung tangan dibuka.

Instrumen yang telah terkontaminasi diletakkan pada wastafel yang berjarak satu meter dari dental unit untuk dibersihkan pada air mengalir oleh asisten operator. Instrumen yang telah terkontaminasi dimasukkan ke dalam baki instrumen dalam keadaan tertutup untuk diantarkan ke ruang CSSD (Central Sterile Supply Department). Sampai di ruangan, pembersihan alat terlebih dahulu dilakukan dengan menggunakan sarung tangan dari karet tebal dan dilakukan dengan air, sikat, spons, dan deterjen. Setelah pencucian dilakukan, langkah selanjutnya ialah memasukkan alat ke dalam mesin washer. Setelah alat kering, maka alat dibungkus dan dimasukkan ke dalam autoklaf untuk disterilkan. Hasil yang ada menunjukkan responden sudah memahami pentingnya hal tersebut dilakukan, sehingga semua petugas patuh terhadap tindakan pencegahan infeksi yang dilakukan.

Penanganan sampah medis bekas praktek terbagi atas sampah infeksius dan non infeksius. Hasil penelitian menunjukkan semua $(100 \%)$ responden menempatkan sampah infeksius pada kontainer yang tepat, yaitu tahan bocor dan berwarna kuning dan menempatkan sampah non infeksius pada kontainer berwarna hitam. Namun, pihak rumah sakit tidak menyediakan kontainer yang tepat melainkan hanya diberikan label pada masing-masing kontainer.

Hasil penelitian penatalaksanaan kecelakaan kerja, menunjukkan bahwa tidak ada kecelakaan kerja yang terjadi di poli gigi Rumah Sakit Siloam Manado selama penelitian berlangsung.

\section{SIMPULAN}

Berdasarkan hasil penelitian ini dapat disimpulkan bahwa pencegahan dan pengendalian infeksi silang pada tindakan ekstraksi gigi di Rumah Sakit Siloam Manado belum dilakukan secara maksimal.

Diharapkan pihak rumah sakit dapat melengkapi fasilitas yang masih kurang dan perlengkapan bahan di poliklinik gigi. Tenaga kesehatan gigi dapat melakukan pencegahan dan pengendalian infeksi silang dengan maksimal agar dapat menekan terjadinya infeksi silang. Pihak masyarakat dapat bersikap kritis terhadap mutu pelayanan kesehatan gigi dan mulut yang diberikan oleh instusi pelayanan dalam hal ini Rumah Sakit Siloam Manado. Evaluasi berkala terhadap pelaksanaan tindakan pencegahan dan pengendalian infeksi. 
DAFTAR PUSTAKA

1. Amir A, Hanafiah JM. Etika Kedokteran dan Hukum Kesehatan. Jakarta: EGC, 2014; p. 28-9.

2. Kementerian Kesehatan RI. Derajat kese-hatan $40 \%$ dipengaruhi lingkungan. Jakarta 2019; p. 1-2.

3. Sardjono B, Sudono, Sari DK, Farida E, Nurindah Rr, Adisetyani Y, et al. Standar pencegahan dan pengendalian infeksi pelayanan kesehatan gigi dan mulut di fasilitas pelayanan kese-hatan. Jakarta: Kemenkes, 2012; p. 1-10.

4. Kementerian Kesehatan Republik Indonesia. Laporan hasil riset kesehatan dasar (Riskesdas) nasional 2018. Jakarta, 2018; p. 93-6.

5. Cottone JA, Terezhalmy GT, Molinari JA. Mengendalikan Penyebaran Infeksi pada Praktik Dokter Gigi. Alih Bahasa: Lilian Y. Jakarta:Widya Medika; 2000.

6. Kalalo DK, Marthen IS. Profil kesehatan provinsi Sulawesi Utara. Sulawesi Utara Dinkes 2016.

7. Wibiwo T, Parisihni K, Haryanto D. Proteksi dokter gigi sebagai pemutus rantai infeksi silang. J PDGI. 2009: 58.

8. Mulyanti S, Putri MH. Pengendalian infeksi silang di klinik gigi. Jakarta: EGC 2012.

9. Wicker S, Rabenau HF. A review of the control and prevention of needle stick injuries. European Infectious Disease. 2011; 5(1): 59.

10. Suleh M, Wowor VNS, Mintjelungan CN. Pengendalian dan pencegahan infeksi di RSGM Unsrat tahun 2015. eG. 2015;3(2):592.

11. Ramdhani W, Kepel B, Parengkuan W. Tindakan pencegahan dan pengendalian infeksi pada perawatan periodonsia di RSGM PSPDG FK Unsrat. eG. 2015;3(2):413. 